\title{
SAH TIDAKNYA PEMBUATAN AKTA NOTARIS SECARA ELEKTRONIK BERDASARKAN TEORI HUKUM POSITIF YANG BERLAKU
}

\author{
Oleh: \\ Sonny Gondo Hudaya \\ Prodi Magister Kenotariatan Universitas Surabaya \\ sonnygondo7@gmail.com
}

\begin{abstract}
ABSTRAK
Berkembangnya teknologi modern yang dikenal dengan cyber notary maka menghendaki seluruh jabatan terutama dalam hal ini jabatan notaris untuk menjalankan tugas dan kewenangannya sebagai Notaris dengan cara berbasis teknologi. Sehingga suka tidak suka globalisasi yang mendatangkan peluang, tantangan, kebaikan dan juga keburukan merupakan tantangan yang harus dihadapi Notaris. Dengan berkembang pesatnya kemajuan teknologi informasi dan telekomunikasi diperlukan sumber daya manusia yang harus dipersiapkan dengan baik dan matang agar peluang di era globaliasai dapat diraih dengan baik oleh Notaris, karena dalam suatu perbuatan hukum antara pihak-pihak terkait sangat diperlukan adanya peran dari Notaris sebagai pihak ketiga yang dipercayakan selayaknya Notaris yang merupakan Pejabat Umum. Dengan begitu Pembuatan akta secara elektronik belum memperoleh landasan hukum yang kuat sehingga belum memberikan jaminan kepastian hukum serta teori hukum hans kelsen yang mengajarkan teori hukum tangga dimana sistem hukum harus tunduk pada hirarki. Kepastian hukum dapat tercapai, jika tidak terdapat ketentuan yang saling bertentangan antara Undang-Undang yang satu dengan yang lainnya. Dalam Pasal 16 ayat (1) huruf m Undang-Undang Jabatan Notaris mewajibkan seorang notaris untuk membacakan akta dihadapan penghadap dengan dihadiri oleh paling sedikit 2 (dua) orang saksi. Sedangkan di dalam Pasal 5 ayat (4) Undang-Undang Informasi Transaksi Elektronik yang memberikan batasan dengan mengecualikan akta notaril tidak temasuk dalam kategori informasi/dokumen elektronik. Dalam substansi hukum yang ada saat ini belum mampu memfasilitasi berbagai kepentingan masyarakat. Karena substansi hukum tersebut belum mengakomodir kepentingan masyarakat, aturan hukum yang ada tidak mampu beradaptasi dengan hal-hal baru yang terjadi di masyarakat, sehingga berdampak tidak adanya jaminan kepastian hukum.
\end{abstract}

Kata Kunci: Akta Notaris, Hukum Positif, Sistem Elektronik. 
Al Qodiri: Jurnal Pendidikan, Sosial dan Keagamaan

Terakreditasi Kemenristekdikti No. 85/M/KPT/2020

Vol 19 No 3 Januari 2022

\section{A. PENDAHULUAN}

Negara Indonesia dalam menjalankan roda pemerintahan diwakili oleh wakil rakyat yang dipilih oleh masyarakat untuk melaksanakan tugas pemerintahan dan memiliki tujuan untuk mewujudkan Visi dan Misi Negara. Salah satu Visi dan Misinya adalah mencerdaskan kehidupan bangsa dan melindungi segenap bangsa Indonesia ini yang terdapat di dalam alinea keempat Pembukaan Undang-Undang Dasar Negara Republik Indonesia 1945 (untuk selanjutnya disingkat "UUD 1945”). Mencerdaskan kehidupan bangsa berkaitan dengan kesehatan warganya. Dalam Melindungi segenap bangsa Indonesia dimaksudkan untuk melindungi kesehatan masyarakatnya. Dengan pemenuhan kebutuhan hidup menimbulkan akibat tingkah laku dari manusia.

Hukum menguasai akibat tingkah laku dari manusia. Hukum mencampuri urusan manusia sebelum manusia dilahirkan dan masih mencampurinya sesudah manusia meninggal. ${ }^{1}$ Oleh karena hal itu, Negara Indonesia disebut negara hukum sesuai dengan Pasal 1 Ayat (3) UUD 1945 setelah diamandemen ke-tiga dan disahkan 10 November 2001yang menjadi hukum positif di negara indonesai. Negara Indonesia adalah negara hukum, dimana memiliki makna bahwa segala aspek kehidupan dalam kemasyarakatan, kenegaraan dan pemerintahan harus senantiasa berdasarkan atas hukum. Hukum merupakan kekuasaan hidup, yaitu sebagai kekuasaan yang memaksa dan mengatur, tetapi hukum juga merupakan kekuasaan yang tetap bergerak dan berkembang karena pengadilan selalu membuat aturan-aturan baru.

Ketentuan-ketentuan hukum yang berlaku sebagai hukum positif juga akan berkembang sesuai dengan tujuannya, terhadap hukum positif pun akan mengalami perubahan dan berkembang sebagaimana aturannya dibutuhkan oleh masyarakatnya pada saat itu. ${ }^{3}$ Nawiasky mengkhususkan pembahasannya pada norma hukum saja sebagai Penganut aliran hukum positif, hukum disinipun diartikan identik dengan perundang-undangan (peraturan yang dikeluarkan oleh pengusaha). Dalam hal ini Undang-Undang Nomor 11 Tahun 2008 tentang Informasi dan Transaksi Elektronik (untuk selanjutnya disebut 'UU ITE”) yang mengatur perkembangnya teknologi komputer dan teknologi komunikasi, dimana berbagai komputer dapat dihubungkan dengan membentuk jaringan komputer yang mengarah pada perkembangan internet. Secara umum, jaringan komputer ialah gabungan komputer dan alat perangkatnya

\footnotetext{
${ }^{1}$ L.J. Van Apeldoorn, “Pengantar Ilmu Hukum” (Jakarta: PT Pradnya Paramita, 2008), Hlm.6

${ }^{2}$ Ibid., Hlm.5

${ }^{3}$ R. Abdoel Djamali, “Pengantar Ilmu Hukum” (Jakarta: PT Raja Grafindo Persada, 2000), Hlm.7
} 
yang terhubung dengan saluran komunikasi yang memfasilitasi komunikasi diantara pengguna dan memungkinkan para penggunanya untuk saling menukar data dan informasi. ${ }^{4}$ Hal ini tentu sangat berpengaruh dan bermanfaat terhadap kegiatan masyarakat terutama dalam menjalankan kehidupan sehari-hari, khususnya dalam masa Pandemi Corona Virus Disease 2019 (untuk selanjutnya disebut "COVID-19") yang hingga saat ini melanda seluruh dunia.

Untuk mengatasi Pandemi COVID-19 ini Pemerintah mengeluarkan peraturan yang harus ditaati demi melindungi dan mensejahterakan rakyatnya. Salah satu peraturan yang dikeluarkan pemerintah adalah Peraturan Pemerintah Republik Indonesia No. 21 tahun 2020 tentang Pembatasan Sosial Berskala Besar Dalam Rangka Percepatan Penanganan COVID-19 (untuk selanjutnya disebut "PP No. 21/2020”) yang bertalian dengan Instruksi Menteri Dalam Negeri No. 01 Tahun 2021 tentang Pemberlakuan Pembatasan Kegiatan Untuk Pengendalian Pernyebaran COVID-19 yang ditujukan untuk daerah DKI Jakarta, Jawa Tengah, Banten, Jawa Tengah, Yogyakarta, Jawa Timur dan Bali (untuk selanjutnya disebut "PPKM") yang sampai saat ini masih berlaku dengan peraturan turunannya. Filosofi dikeluarkan PP No. 21/2020 tercantum dalam konsideran butir B yang menyatakan "bahwa dampak penyebaran COVID-19 telah mengakibatkan terjadi keadaan tertentu sehingga perlu dilakukan upaya penanggulangan, salah satunya dengan tindakan PSBB dan dilanjutkan dengan PPKM. Dengan adanya PSBB dan PPKM ini menimbulkan masalah hukum terkait dengan pembuatan akta notaris. Para penghadap dan notaris pastinya akan sulit untuk bertemu secara tatap muka seperti biasanya karena keadaan yang tidak memungkinkan selama COVID-19 ini berlangsung. Sehingga dalam era globalisasi ini merupakan era yang harus dijalankan oleh setiap warga yang salah satunya memiliki profesi sebagai Notaris. Hal ini tidak dapat dihindari karena ketika seseorang tidak bisa mengikuti suatu perkembangan jaman maka akan terjadi ketertinggalan bagi orang tersebut. Sehingga suka tidak suka globalisasi yang mendatangkan peluang, tantangan, kebaikan dan juga keburukan merupakan tantangan yang harus dihadapi seorang Notaris. Dengan berkembang pesatnya kemajuan teknologi informasi dan telekomunikasi diperlukan sumber daya manusia yang harus dipersiapkan dengan baik dan matang agar peluang di era globaliasai dapat diraih dengan baik.

Era ini membuat peran Notaris untuk dapat turut serta dalam perkembangan teknologi informasi dan telekomunikasi ini, karena dalam suatu perbuatan hukum antara pihak-pihak terkait sangat diperlukan adanya peran dari Notaris sebagai pihak ketiga yang dipercayakan

\footnotetext{
${ }^{4}$ Josua Sitompul, “Cyberspace, Cybercrime, Cyberlaw” (Jakarta: Tata nusa, 2012), Hlm. 20.
} 
selayaknya Notaris yang merupakan Pejabat Umum. Sehingga peran Notaris dalam perkembangan teknologi informasi dan telekomunikasi serta apabila dikaitkan dengan keadaan pandemi COVID-19 sangat dibutuhkan. Notaris dalam hal ini dituntut untuk bisa dan mampu menggunakan konsep cyber notary agar dapat menciptakan suatu pelayanan jasa yang cepat, tepat, dan efisien. Sehingga mampu untuk mempercepat laju pertumbuhan ekonomi yang ada di Indonesia. Kewenangan notaris dalam bidang Cyber Notary secara eksplisit disebut dalam penjelasan Pasal 15 ayat (3) Undang-Undang Nomor 2 Tahun 2014 tentang Perubahan atas Undang-Undang Nomor 30 Tahun 2004 tentang Jabatan Notaris (utuk selanjutna disebut "UUJNP") yang berbunyi "Yang dimaksud dengan "kewenangan lain yang diatur dalam peraturan perundang- undangan", antara lain, kewenangan mensertfifikasi transaksi yang dilakukan secara elektronik (cyber notary), membuat akta, ikrar wakaf, dan hipotek pesawat terbang." Berdasarkan penjelasan pasal tersebut, bahwa notaris mempunyai kewenangan untuk mensertifikasi transaksi yang dilakukan secara cyber notary. Istilah sertifikasi berasal dari bahasa Inggris yaitu 'certification' yang berarti keterangan, pengesahan. ${ }^{5}$ Sertifikasi yang dilakukan oleh Notaris selanjutnya disebut akta notaris seperti yang tertuang pada Pasal 1 angka 7 UUJNP, menyatakan bahwa: “Akta Notaris yang selanjutnya disebut Akta adalah akta autentik yang dibuat oleh atau di hadapan Notaris menurut bentuk dan tata cara yang ditetapkan dalam Undang-Undang ini” Kemudian jika dilihat pada Pasal 16 ayat (1) huruf m UUJNP yang menyatakan bahwa dalam menjalankan jabatannya Notaris berkewajiban membacakan akta di hadapan penghadap dengan dihadiri oleh paling sedikit 2 (dua) orang saksi atau 4 (empat) orang saksi khusus untuk pembuatan akta wasiat dibawah tangan dan ditandatangani pada saat itu juga oleh penghadap, saksi, dan Notaris. Berdasarkan rumusan tersebut jelas disyaratkan adanya pertemuan fisik dan/atau secara langsung antar para pihak dihadapan Notaris secara langsung face to face. Sedangkan dalam konsep cyber notary justru sebaliknya, bahwa pertemuan fisik ini tidak mutlak adanya, karena fungsinya digantikan oleh alat telekomunikasi. Disinilah timbulnya konflik pertentangan hukumnya antara produk akta Notaris secara konvensional dengan produk berupa akta notaris secara elektronik atau Cyber Notary.

\footnotetext{
${ }^{5}$ John M. Echols dan Hassan Shadily, Kamus Hukum Inggris Indonesia, Gramedia Utama, Jakarta, 2012,
} hlm. 110. 
Al Qodiri: Jurnal Pendidikan, Sosial dan Keagamaan

Terakreditasi Kemenristekdikti No. 85/M/KPT/2020

Vol 19 No 3 Januari 2022

\section{B. HASIL DAN PEMBAHASAN}

John Austin mengemukakan bahwa hukum adalah perintah yang bersifat umum yang ditetapkan yang berdaulat sebagai pedoman perilaku bagi masyarakat dibawah penguasa. Perintah yang bersifat umum merupakan hukum positif oleh karena itu kemajuan teknologi informasi dan komunikasi yang sangat pesat telah membuka tahap baru bagi masyarakat untuk memperoleh informasi secara otonom. Sekat-sekat informasi dengan sendirinya menghilang oleh inisiatif kuat individu yang ingin mengetahui lebih jauh apa yang terjadi sekitarnya. Masyarakat memiliki akses terhadap sumber informasi dimanapun mereka berada. Konsekuensinya, masyarakat menjadi kritis dan tanggap terhadap banyak hal yang berkembang. Perkembangan teknologi informasi dan telekomunikasi merupakan suatu yang harus ada dan diikuti oleh masyarakat modern saat ini. Sumbangan teknologi informasi dan komunikasi terhadap peradaban dan kesejahteraan manusia tidaklah dapat dipungkiri. Seperti yang kita ketahui bahwa di era serba modern seperti saat ini, peran teknologi informasi dalam kehidupan sehari-hari tentunya sangat berpengaruh. Hal ini tidak terlepas dari aktivitas kita yang kerap kali ditunjang dengan teknologi informasi itu sendiri yang mampu menjawab tuntutan pekerjaan yang lebih cepat, mudah, murah dan menghemat waktu. Kemajuan teknologi menjadi jawaban dari kemajuan globalisasi yang kian menyelimuti dunia.

Perkembangan teknologi dan komunikasi yang begitu pesat, telah memunculkan adanya sebuah media baru. Keberadaan media baru ini diantaranya adalah munculnya internet. Internet sebagai sebuah produk teknologi komunikasi, meski sudah berkembang sejak puluhan tahun yang lalu, namun hingga saat ini keberadaannya semakin dibutuhkan oleh hampir semua masyarakat dunia. Perkembangan internet, yang juga disebut teknologi jaringan komputer global, pada akhirnya telah menciptakan suatu dunia baru yang dinamakan cyberspace, yang kemudian diterjemahkan menjadi dunia maya atau dunia mayantara. Jusuf Jacobus Setyabudi dalam Tutik Tri Wulan Tutik mengatakan bahwa: cyberspace adalah sebuah dunia komunikasi berbasis komputer, yang menawarkan suatu realitas baru, yaitu realitas virtual (virtual reality). Lebih lanjut Onno W. Purbo dalam Tutik Tri Wulan Tutik mengatakan bahwa: internet sering disosialisasikan sebagai media tanpa batas. Dimensi ruang, waktu, birokrasi, kemapanan dan tembok strukturisasi yang selama ini ada di dunia nyata yang mudah di tembus oleh teknologi informasi. ${ }^{6}$ Oleh karena itu demokratisasi, keterbukaan, kebebasan berbicara, kompetisi bebas,

\footnotetext{
${ }^{6}$ Titik Triwulan Tutik. "Hukum Perdata Dalam Sistem Hukum Nasional.” (Jakarta: Media Group, 2014)
} Hlm. 370 
perdagangan bebas yang diimbangi oleh kemampuan intelektual dan profesionalisme yang tinggi yang menjadi ciri khas dunia informasi mendatang di era globalisasi.

Dalam era globalisasi yang bertepatan dengan adanya penyebaran COVID-19 yang masih berlangsung, masyarakat mau tidak mau harus mengikuti protokol kesehatan yang telah ditentukan, salah satunya adalah PSBB dimana protokol ini menimbulkan masalah hukum terkait dengan pembuatan akta notaris. Para penghadap dan Notaris menjadi sulit untuk bertemu secara tatap muka seperti biasanya karena keadaan yang tidak memungkinkan. Sebagai masyarakat yang taat akan peraturan hukum yang ada masyarakat harus mengikuti protokol PSBB dan PPKM demi terjaminnya kesehatan dan agar pandemi COVID-19 yang terjadi ini cepat selesai dan berlalu. Oleh karena itu diterapkan work from home atau kerja di rumah melalui media elektronik yang dilakukan secara online, yang dimana work from home ini juga berlaku bagi lingkup kerja Notaris, dimana Notaris, penghadap dan saksi tidak lagi dapat bertemu seperti biasanya, sebagaimana surat himbauan yang dikeluarkan oleh Pengurus Pusat Ikatan Notaris Indonesia (untuk selanjutnya disebut "INI") Nomor 65/33-III/PP-INI/2020 tertanggal 17 Maret 2020 yang menghimbau bahwa:

"1. Seluruh kantor Notaris diwajibkan untuk melaksanakan protokol pencegahan penyebaran COVID-19 yang telah diterbitkan dan sesuai jangka waktu yang ditentukan oleh pemerintah.

2. Bagi rekan-rekan pengurus agar sementara waktu membatasi/mengurai atau menunda kegiatan yang berbentuk seminar, diskusi hukum, FGD, atau kegiatan lain yang sejenis yang sifatnya mengumpulkan banyak anggota/orang.

3. Mengurangi aktivitas di kantor atau di luar kantor, apabila tidak ada keperluan yang mendesak, pekerjaan-pekerjaan yang wajib diselesaikan semaksimal mungkin dapat diselesaikan di rumah.

4. Dalam hal mengharuskan melaksanakan tugas di luar rumah/kantor, hindari kerumunan orang atau tetap menjaga jarak dengan klien.

5. Selalu menjaga Kesehatan dan kebersihan kantor.

Sehubungan dengan hal tersebut diatas munculah perdebatan mengenai adanya akta yang dibuat secara elektronik. Pembuatan akta notaris secara elektronik ini menimbulkan keuntungan dan tantangan bagi Notaris sendiri yaitu harus meningkatkan ilmu pengetahuannya dan kecakapannya dalam menggunakan perangkat elektronik, sedangkan keuntungannya adalah penerapan pembuatan akta secara elektronik ini dapat mencegah atau memutus mata rantai pandemi COVID-19. Pengertian dari Notaris sendiri berdasarkan Pasal 1 ayat (1) UUJNP, menyatakan bahwa: "Notaris adalah pejabat umum yang berwenang untuk membuat 
akta autentik dan memilki kewenangan lainnya sebagaimana dimaksud dalam undang-undang ini atau berdasarkan undang-undang lainnya." Notaris adalah pejabat atau profesional hukum yang disumpah untuk bertindak sesuai dengan hukum yang semestinya, sehingga dapat dikatakan notaris sangat diperlukan untuk kepastian legalitas perbuatan maupun untuk mencegah adanya perbuatan melawan hukum.

Berdasarkan UUJNP, dapat dilihat bahwa Notaris memiliki peran dan fungsi yang penting dalan legalitas transaksi di Indonesia, bahkan Notaris juga dipahami sebagai pihak ketiga yang terpercaya. Jasa seorang Notaris telah menjadi kebutuhan masyarakat, tidak hanya dalam pembuatan akta, melainkan juga sebagai saksi atau penengah dari transaksi yang dilakukan. ${ }^{8}$ Berdasarkan pengertian tersebut diatas dapat dikatakan bahwa seorang Notaris memiliki wewenang dalam membuat sebuah akta, dimana wewenang (atau sering ditulis dengan istilah kewenangan) merupakan suatu tindakan hukum yang diatur dan diberikan kepada suatu jabatan berdasarkan peraturan perundang-undangan yang berlaku yang mengatur jabatan yang bersangkutan dan memiliki batasan sebagaimana tercantum dalam peraturan perundang- undangan yang mengaturnya. Undang-Undang No. 30 Tahun 2004 tentang Jabatan Notaris (untuk selanjutnya disebut "UUJN") maupun UUJNP belum secara tegas mengatur mengenai kewenangan Notaris dalam pembuatan akta notaris secara elektronik.

Definisi akta notaris berdasarkan Pasal 1 angka 7 UUJNP adalah: “Akta Notaris yang selanjutnya disebut Akta adalah akta autentik yang dibuat oleh atau di hadapan Notaris menurut bentuk dan tata cara yang ditetapkan dalam Undang-Undang ini.” berdasarkan Pasal 1 angka 7 memberikan pemahaman bahwa akta notaris harus dibuat dihadapan Notaris, artinya para pihak harus menghadap kepada notaris. Ketentuan dari pasal 1868 Kitab Undang-Undang Hukum Perdata (untuk selanjutnya disebut "KUH Perdata") yang di dalamnya mengatur akta autentik termasuk juga akta notaris, wajib dibuat dalam bentuk yang telah ditentukan oleh undangundang dan akta tersebut dibuat oleh atau dibuat dihadapan pejabat umum yang berwenang di tempat di mana akta itu dibuat, sehingga apabila akta yang dibuat tersebut telah sesuai dengan

7 Rudyanti Dorotea Tobing. Aspek-Aspek Hukum Bisnis, Pengertian, Asas, Teori dan Praktik. (Yokyakarta: Lasbang Justia, 2012) Hlm. 6

${ }^{8}$ Edmon Makarim. Notaris dan Transaksi Elektronik, Kajian Hukum Tentang Cybernotary atau Elektronik Notary, (Jakarta:Sinar Grafika, 2014), Hlm 7 
bentuk yang ditentukan oleh undang-undang dan pejabat umum yang membuat akta tersebut sesuai dengan kewenangannya maka akta tersebut dapat digolongkan sebagai akta autentik.

Sebuah akta autentik merupakan dokumen yang sah dan dapat menjadi alat bukti yang sempurna. Sempurna di sini berarti hakim menganggap semua yang tertera dalam akta merupakan hal yang benar, kecuali ada alat bukti lain yang dapat membuktikan bahwa isi akta pertama tersebut adalah tidak benar. Ada beberapa alasan yang menunjang kekuatan hukum sebuah akta autentik. Akta autentik dibuat dihadapan seorang pejabat umum sehingga legalitasnya dapat dipastikan, ditambah lagi bahwa pejabat umum tidak memiliki keberpihakan dalam pembuatan akta. Hal ini berbeda dengan akta yang dibuat sendiri, meskipun disaksikan pihak ketiga, tetapi hal itu tidak dapat dijadikan jaminan. Dapat saja pihak-pihak yang terlibat pembuatan akta menyangkal keterlibatannya. Hal ini dapat terjadi karena mereka mempunyai kepentingan sendiri-sendiri, berbeda dengan Notaris yang pejabat umum yang tidak memiliki keberpihakan dalam pembuatan sebuah akta. Dengan demikian, pengertian akta notaris di atas, menunjukkan bahwa peluang untuk membuat akta notaris dengan memanfaatkan perkembangan teknologi informasi sangat kecil, mengingat UUJN dan UUJNP mengharuskan pembuatan akta dilaksanakan dihadapan notaris.

Demikian pula pengaturan yang dapat dijadikan sebagai landasan hukum pembuatan akta secara elektronik dalam UU ITE. Undang-Undang ini secara tegas memberikan pembatasan terhadap kewenangan notaris dalam membuat akta secara elektronik. Hal ini dapat dilhat dalam ketentuan Pasal 5 ayat (4) UU ITE, yang menyebutkan bahwa Informasi Elektronik dan/atau Dokumen Elektronik sebagaimana dimaksud pada ayat (1) tidak berlaku untuk surat yang menurut Undang-Undang harus dibuat dalam bentuk tertulis dan surat beserta dokumennya yang menurut Undang-Undang harus dibuat dalam bentuk akta notaris atau akta yang dibuat oleh pejabat pembuat akta. Sehingga akta notaris yang dibuat secara elektronik tidak memperoleh kekuatan hukum sebagai bukti yang sah menurut ketentuan UU ITE.

Dengan pembatasan makna dari informasi elektronik/dokumen elektronik yang diatur dalam Pasal 5 ayat (4), maka akta notaris yang dibuat secara elektronik oleh Notaris dianggap tidak dapat menjadi alat bukti yang sah. Maka, keautentikan atau kekuatan pembuktian dari akta yang dibuat oleh Notaris dalam hal ini tidak ada dan tidak terpenuhi. Ketentuan hukum tentang akta autentik yang diatur dalam UUJN, UUJNP dan UU ITE, memberikan pemahaman bahwa penerapan perkembangan teknologi informasi dalam pembuatan akta autentik secara elektronik oleh Notaris masih sulit untuk diterapkan, mengingat ketentuan hukum yang mengatur tentang otensitas akta autentik masih menjadi hambatan dalam proses pembuatan akta 
yang dibuat secara elektronik oleh Notaris. Edmon Makarim menjelaskan bahwa: "Sebenarnya tidak ada larangan pembuatan salinan elektronik dalam undang-undang jabatan notaris, tetapi akan potensial muncul masalah karena adanya keharusan pembacaan dan penanda waktu yang menunjukkan tanggal dan/atau waktu di mana peristiwa tertentu terjadi (time stamping). Oleh karena itu para pihak yang bertransaksi dengan notaris terlebih dahulu menyepakati waktu yang akan dipakai dalam suatu transaksi elektronik." Mengingat Notaris sebagai pejabat umum berwenang untuk membuat akta autentik, bahwa keautentik-an sebuah akta dibuat dihadapan Notaris sesuai dengan kewajiban yang harus dilakukan untuk akta yang dibuatnya hal ini dinyatakan dalam Pasal 16 ayat (1) UUJNP huruf c, dan m: “c. Melekatkan surat dan dokumen serta sidik jari penghadap pada Minuta Akta m. Membacakan Akta di hadapan penghadap dengan dihadiri oleh paling sedikit 2 (dua) orang saksi, atau 4 (empat) orang saksi khusus untuk pembuatan akta wasiat di bawah tangan, dan ditandatangani pada saat itu juga oleh penghadap, saksi, dan notaris."

Dengan adanya akta elektronik mengakibatkan tidak dapat diberikannya kepastian hukum dan kemanfaatan hukum bagi masyarakat. Dalam menjalankan atau melaksanakan tugas jabatan Notaris yang baik ada asas-asas yang harus dijadikan pedoman salah satunya ialah asas kepastian hukum. Habib Adjie mengemukakan: "Notaris dalam menjalankan tugas jabatannya wajib berpedoman secara normatif kepada aturan hukum yang berkaitan dengan segala tindakan yang akan diambil untuk kemudian dituangkan dalam akta. Bertindak berdasarkan aturan hukum yang berlaku akan memberikan kepastian kepada para pihak, bahwa akta yang dibuat dihadapan atau oleh Notaris telah sesuai dengan aturan hukum yang berlaku, sehingga jika terjadi permasalahan, akta notaris dapat dijadikan pedoman oleh para pihak." ${ }^{10} 10$ Karena hal ini maka pembuatan akta notaris sangat tidak dimungkinkan untuk dibuat secara elektronik, karena kehadiran seorang Notaris, penghadap dan saksi adalah suatu kewajiban sehingga dapat dibuat berita acara yang berisi uraian Notaris yang dilihat serta disaksikan Notaris sendiri yang dapat menjamin para pihak serta memberikan kepastian kepada para pihak.

Namun, permasalahan mengenai pembuatan akta notaris secara elektronik juga ditemukan dalam Undang-Undang No. 40 Tahun 2007 tentang Perseroan Terbatas (untuk selanjutnya disebut "UUPT"), dimana dalam Rapat Umum Pemegang Saham (untuk

\footnotetext{
${ }^{9}$ Emma Nurita. Cybernotary Pemahaman Awal dan Konsep Pemikiran. (Jakarta: Refika Aditama, 2014). HIm 8

${ }^{10}$ Habib Adjie, Hukum Notaris Indonesia Tafsir Tematik Terhadap UU No. 30 Tahun 2004 Tentang Jabatan Notaris, (Bandung:PT. Refika Aditama, 2014). Hlm 36
} 
selanjutnya disebut "RUPS") sebagaimana diatur dalam Pasal 77 ayat (1) UUPT tidak hanya berbenturan dengan ketentuan yuridis mengenai kehadiran dari Notaris, para pihak dan juga saksi sebagaimana ditegaskan dalam Pasal 16 ayat (9) UUJNP. Tetapi, persoalan ini pun bertentangan dengan adanya pembatasan terhadap pembuatan akta notaris secara elektronik dalam Pasal 5 ayat (4) UU ITE. Apabila dilihat pasal-pasal tersebut diatur dalam UndangUndang yang berbeda, dimana salah satu pasalnya dalam melaksanakan RUPS mengeliminasi ketentuan mengenai kewajiban Notaris sebagaimana Pasal 16 ayat (1) huruf c dan m, ketiga peraturan yang bertentangan tersebut dapat menyudutkan Notaris ketika akta RUPS tersebut bermasalah dan/atau bila dijadikan sebgai bukti dalam proses peradilan, serta Notaris dapat dikenakan sanksi berdasarkan Pasal 16 ayat (11) UUJNP. Bila dilihat dengan asar preferensi perundang-undangan lex specialis derogate legi genrali, asas ini merujuk pada tiga peraturan perundang- undangan yang secara hierarkis mempunyai kedudukan yang sama, dan perbuatan hukum tersebut diperintahkan Undang-Undang, dan yang membuat Undang-Undang tersebut adalah lembaga yang sama.

Berdasarkan hal tersebut, maka masih diperlukan pengkajian lebih lanjut tentang kemungkinan dibuatnya akta notaris dengan menggunakan media elektronik, dengan berbagai pendekatan, terutama dengan pendekatan perundang-undangan. Substansi hukum dalam pembuatan akta secara elektronik belum terakomodasi atau peraturannya belum tersedia seutuhnya baik dalam UUJN, UUJNP, UUPT maupun dalam UU ITE. Padahal, UUJN dan UUJNP kedua Undang-Undang tersebut merupakan landasan hukum bagi Notaris dalam menangkap peluang pembuatan akta secara elektronik sesuai dengan tuntutan dan perkembangan masyarakat modern saat ini. Meskipun di dalam UUJN, UUJNP dan UU ITE pembuatan akta secara elektronik belum dimungkinkan untuk dilaksanakan oleh notaris, peluang pembuatan akta secara elektronik tetap terbuka dengan diaturnya pembuatan akta secara elektronik. Hanya dalam pelaksanaannya belum dapat diterapkan, mengingat kendala yuridis yang masih dihadapi oleh Notaris. Berbagai kendala yang telah dijelaskan di atas, memberikan pemahaman mengenai langkah konkrit yang dapat dilakukan untuk mengimplementasikan perkembangan teknologi informasi dalam pembuatan akta autentik. Secara yuridis, langkah yang dapat ditempuh adalah dengan melakukan revisi terhadap UUJN, UUJNP dan UU ITE, yang kemudian dilakukan harmonisasi atau penyesuaian hukum antara kedua undang-undang tersebut dengan ketentuan yang diatur dalam Hukum Perdata. Secara substansial beberapa pasal yang termuat dalam UUJN dan UUJNP harus dilakukan perubahan. 
Oleh sebab, pasal-pasal tersebut menjadi salah satu faktor yang menjadi hambatan bagi notaris dalam pembuatan akta secara elektronik.

Dengan demikian, untuk menciptakan kepastian hukum dan kemanfaatan hukum bagi masyarakat, perlu mengharmonisasikan peraturan perundang- undangan yang terkait dengan kewenangan notaris dalam pembuatan akta secara elektronik, yaitu antara UUJN dengan UU ITE dan antara UUPT dengan UUJN. Sehingga notaris tidak lagi mengalami permasalahan yuridis menyangkut kewenangannya dalam membuat akta secara elektronik. Demikian pula dengan masyarakat yang membutuhkan jaminan terhadap perbuatan hukum yang dilakukan secara elektronik hanya dapat dicapai dengan terakomodirnya kewenangan notaris dalam pembuatan akta secara elektronik dalam undang-undang, mengingat dalam perkembangan teknologi yang sangat pesat di era globalisasi dimana segala sesuatu dapat diperoleh dengan bantuan internet/online.

\section{KESIMPULAN}

Berdasarkan pembahasan diatas dapat diambil kesimpulan bahwa dengan berkembangnya teknologi modern yang dikenal dengan cyber notary maka menghendaki seluruh jabatan terutama dalam hal ini jabatan notaris untuk menjalankan tugas dan kewenangannya sebagai Notaris dengan cara berbasis teknologi. Dalam hal ini salah satu caranya yaitu dengan pembuatan segala jenis akta dilakukan melalui media elektronik yang mana tidak memerlukan lagi bertemu secara fisik tatap muka sehingga konsep ini tidak perlu secara langsung datang ke kantor notaris. Pembuatan akta secara elektronik belum memperoleh landasan hukum yang kuat, bedasarkan hukum positif yang dikemukakan oleh john Austin serta teori hukum hans kelsen yang mengajarkan teori hukum tangga dimana hukum sistem hukum harus tunduk pada hirarki sehingga belum memberikan jaminan kepastian hukum. Kepastian hukum dapat tercapai, jika tidak terdapat ketentuan yang saling bertentangan antara UndangUndang yang satu dengan yang lainnya. Peluang notaris untuk membuat akta secara elektronik dalam UUPT, tidak dapat diterapkan karena belum adanya sinkronisasi (bertentangan) dengan UUJN, UUJNP dan UU ITE. Pasal 16 ayat (1) huruf m UUJNP mewajibkan seorang notaris untuk membacakan akta dihadapan penghadap dengan dihadiri oleh paling sedikit 2 (dua) orang saksi. Sedangkan di dalam Pasal 5 ayat (4) UU ITE yang memberikan batasan dengan mengecualikan akta notaril tidak temasuk dalam kategori informasi/dokumen elektronik.

Ketidaksesuaian antara UUJN, UUJNP, UU ITE, dan UUPT terkait kewenangan Notaris membuat akta secara elektronik jelas menjadi hambatan tersendiri bagi Notaris. Substansi hukum yang ada saat ini belum mampu memfasilitasi berbagai kepentingan 
masyarakat. Karena substansi hukum tersebut belum mengakomodir kepentingan masyarakat, aturan hukum yang ada tidak mampu beradaptasi dengan hal-hal baru yang terjadi di masyarakat, sehingga berdampak tidak adanya jaminan kepastian hukum. Substansi hukum belum bersifat futuristik, karena pengaturan kewenangan Notaris tidak dapat mengantisipasi kejadian yang mungkin muncul di kemudian hari, yaitu tuntutan masyarakat agar Notaris mampu membuat akta secara elektronik. Struktur hukum yang dibangun belum mampu mendorong terlaksananya pelayanan jasa secara elektronik oleh Notaris dengan baik dan maksimal. Ditambah lagi budaya hukum masyarakat yang cenderung lebih percaya menggunakan fasilitas konvensional dibanding dengan teknologi. Selain itu, notaris juga belum sepenuhnya siap dalam memberikan pelayanan jasa secara elektronik, karena diperlukan penguasaan Informasi dan Teknologi yang baik. 
Al Qodiri: Jurnal Pendidikan, Sosial dan Keagamaan

Terakreditasi Kemenristekdikti No. 85/M/KPT/2020

Vol 19 No 3 Januari 2022

\section{DAFTAR PUSTAKA}

Darji darmodiharjo dan shidarta, Pokok-pokok Filsafat Hukum, PT. Gramedia Pustaka Utama, 2004

Edmon Makarim. Notaris dan Transaksi Elektronik, Kajian Hukum Tentang Cybernotary atau Elektronik Notary, Sinar Grafika, Jakarta, 2014

Emma Nurita. Cybernotary Pemahaman Awal dan Konsep Pemikiran, Refika Aditama, Jakarta, 2014

Habib Adjie, Hukum Notaris Indonesia Tafsir Tematik Terhadap UU No. 30 Tahun 2004 Tentang Jabatan Notaris, PT. Refika Aditama, Bandung, 2014

John M. Echols dan Hassan Shadily, Kamus Hukum Inggris Indonesia, Gramedia Utama, Jakarta, 2012

Josua Sitompul, Cyberspace, Cybercrime, Cyberlaw, Tata nusa, 2012

L.J. Van Apeldoorn, Pengantar Ilmu Hukum, PT. Pradnya Paramita, Jakarta, 2008

R. Abdoel Djamali, Pengantar Ilmu Hukum, PT. Raja Grafindo Persada, Jakarta, 2000

Rudyanti Dorotea Tobing. Aspek-Aspek Hukum Bisnis, Pengertian, Asas, Teori dan Praktik.

Lasbang Justia, Yokyakarta, 2012

Titik Triwulan Tutik. Hukum Perdata Dalam Sistem Hukum Nasional, Media Group, Jakarta, 2014

Undang-Undang:

Kitab Undang-Undang Hukum Perdata

Undang-Undang No. 30 Tahun 2004 Tentang Jabatan Notaris

Undang-Undang No. 2 Tahun 2014 Tentang Perubahan Atas Undang-Undang Nomor 30 Tahun 2004 Tentang Jabatan Notaris

Undang-Undang Nomor 11 Tahun 2008 Tentang Informasi Dan Transaksi Elektronik 